\title{
EXPORT OF AGRICULTURAL AND FOOD PRODUCTS OF UKRAINE: CONCEPT OF PROSPECTS
}

\begin{abstract}
The current global conditions of the export food market are analysed and the corresponding trends are revealed. It is substantiated that the priority direction of exports to the developed countries of the world are processed products of agricultural raw materials with significant added value. Two opposite trends have been identified - the world's population is constantly growing, while the area of agricultural production, as well as marine fish stocks have a steady downward trend, which leads to the introduction of intensive technologies for growing crops and increase in exports. It is proved that under certain conditions Ukraine has a good chance to increase food exports, including those of highly processed food. It is determined that in order to implement the task of increasing food exports, it is necessary to develop a concept of prospects for these exports. The basic provisions, principles and model of the concept of prospects for Ukrainian food exports are formed taking into account the potential raw agricultural resources created if innovative technologies of food industry production are introduced. It is noted that the proposed concept is based on the agro-industrial potential of Ukraine and is realistic even before implementation.
\end{abstract}

(C) Yurii Pasichnyk, 2020.

Pasichnyk Yurii, Professor, Leading Specialist at National Scientific Centre «Institute of Agrarian Economics», Ukraine. ORCID: 0000-0001-9742-1378 Email: y.v.pasich@gmail.com. 


\section{Key words:}

Grain balance, exports, price indexation, concept, trends.

JEL: F13, F14, F17.

\section{Introduction}

Ensuring the dynamic social development of Ukraine should be carried out using all potential opportunities. In this context, the agro-industrial complex has good prospects, given the favourable conditions of world food markets, fertile soils, large swathes of agricultural land, opportunities for tertiary technological processing of agricultural raw materials. However, to date, these exports opportunities are used to a much lesser potential given the supply of convenience food. That is why the concept of prospects for the export of agricultural and ready-to-eat food products of Ukraine is proposed, which will help increase the number of jobs, budget revenues at all levels and help stabilize the difficult socioeconomic situation.

\section{Problem statement}

Food has traditionally played an important role in the functioning of states, as it is the basis of human life. The transformational processes taking place in the world to provide food for the Earth's population indicate permanent changes in the structure of population nutrition among the leading exporting and importing countries. However, given the growing world population and declining acreage, the problem of food supply is relevant and, in this context, Ukraine has significant prospects for growth in food exports. At the same time, the structure of Ukrainian food exports consists mainly of agricultural raw materials, without a significant increase in the volume of processed food, so the theoretical justification for solving this problem in modern realities becomes particularly clear and requires proper scientific substantiation. 


\section{Analysis of recent research and publications}

Given the potential opportunities of Ukraine's foreign trade relations with the world and European society on food supplies, this issue is investigated in the works of Ukrainian scientists. Among them O. Bazhenova (2019), A. Kasych (2015), N. Nepriadkina (2018), H. Artamonova (2019), Ye. Markova and T. Shestakovska (2017), I. Gryshova (2016), L. Naumova (2016), O. Okhrimenko (2018), M. Pugachov (2017), N. Burlaka and O. Baltremus (2016), E. Pakhucha, Y. Filimonov, and L. Leshchenko (2019). Assessing these and other scientific papers on this issue, we note that the prospects for exports of agricultural and food products of Ukraine, in particular in the context of scientific substantiation for potential increase in exports of processed products is insufficient coverage, so the proposed article focuses on this aspect of the issue.

\section{Aim of the article}

The main purpose of this article is to identify the potential opportunities of Ukraine for food exports, in particular food products of tertiary technological processing, as well as to substantiate the concept of its prospects.

\section{Research findings}

Modern world economic processes in food industry confirm the urgency of providing sustenance to the world's population. In modern conditions, food security is a priority state task in most countries of the world. Let us consider the following aspects of this issue.

1. Population growth. According to a group of Brazilian scientists who used UN data to model what the population growth will be, a forecast was made (Table 1).

Based on these data, we conclude that due to the permanent growth of the population on all continents except Europe, the need for food will increase as well. As for Europe, the possibility of insignificant growth is conclusively not ruled out either due to the high standard of living in some economically developed countries and the corresponding migration processes. Thus, there is every reason to believe that there is a growing permanent need for food, and Ukraine may have some advantages in this context. 
Table 1

World population growth forecast

\begin{tabular}{|l|c|c|c|c|c|}
\hline \multirow{2}{*}{ Continent } & \multicolumn{5}{|c|}{ Population (million) } \\
\cline { 2 - 6 } & 2015 & 2020 & 2030 & 2040 & 2050 \\
\hline Africa & 1194 & 1353 & 1704 & 2100 & 2358 \\
\hline Asia & 4420 & 4623 & 4917 & 5154 & 5257 \\
\hline Europe & 741 & 743 & 739 & 729 & 716 \\
\hline South America & 632 & 664 & 718 & 757 & 780 \\
\hline North America & 356 & 369 & 395 & 417 & 435 \\
\hline World & 7383 & 7795 & 8551 & 9210 & 9772 \\
\hline
\end{tabular}

Source: do Nascimento, R., Ferreira, O., De Paula, A., Neto, V. (2019).

2. Hunger. According to the FAO report for 2018 , the number people suffering from hunger is gradually increasing. There are 820 million - or about one in nine - hungry people in the world (FAO 2019). This problem cannot be solved at once nor on a permanent basis, because it is caused by a number of factors, in particular, climatic, military, environmental, demographic, mental, etc. The international community is trying to help address the most pressing issues in this area, but current efforts are insufficient.

3. Decrease in the area of food resources. The 2018 FAO report (2019) revealed the following facts: «On average, $60 \%$ of local livestock breeds are at risk of extinction in the 70 countries that have risk status information. Globally, the risk status remains unknown for two thirds of local livestock breeds". From what has been reported, out of a total of 7760 local breeds only 79 breeds (less than $1 \%$ ) have sufficient material stored to allow them to be reconstituted in case of extinction. It is estimated that one third of the fish in the oceans are caught, and the share of the world's marine fish stocks within biologically stable levels has decreased from 90 percent in 1974 to 66.9 percent in 2015. Between 2000 and 2015, the world lost Madagascar-sized forests, although the rate of deforestation appears to be slowing. During the period from 2000 to 2015, the share of forest areas in the total land area in the world decreased from 31.1 to 30.7 percent. Forest loss can lead to a number of negative consequences, including the loss of livelihoods in rural communities, carbon emissions, biodiversity loss, and land degradation (FAO 2019). Assessing the relevant negative trends in the presented facts, we conclude that there is a negative trend in the acreage of food sources. If we add the growing urbanization, significant climate change, environmental problems, then it is clear that in the coming decades there will be a threat to food supply of the Earth's population. Expectations of food intensification and waste reduction may not come to be due to force majeure or other processes related to globalization and military conflicts. 
Thus, two opposite trends are observed - an increase in population and a decrease in the factors that shape the world's food resources. vant data.

To identify the criteria for food security worldwide, we will analyse the rele-

Table 2

Total world food resources

\begin{tabular}{|l|c|c|c|c|}
\hline \multirow{2}{*}{ World balance } & $2017 / 18$ & $2018 / 19$ & $\begin{array}{c}2019 / 20 \\
\text { (forecast) }\end{array}$ & $\begin{array}{r}2019 / 20 \text { to } \\
2018 / 19, \%\end{array}$ \\
\cline { 2 - 5 } & \multicolumn{4}{|c|}{ Million tonnes } \\
\hline Production & 2703,0 & 2651,5 & 2722,2 & 2,7 \\
\hline Trade & 421,4 & 411,4 & 413,2 & 0,5 \\
\hline Total utilization & 2657,3 & 2681,5 & 2722,4 & 1,5 \\
\hline including food & 1127,3 & 1142,2 & 1154,9 & 1,1 \\
\hline feed & 949,5 & 954,5 & 971,5 & 1,8 \\
\hline other uses & 580,4 & 584,8 & 595,9 & 1,9 \\
\hline
\end{tabular}

Source: compiled by the author on the basis of FAO Food Outlook - Biannual Report on Global Food Markets (2019).

According to these data, world food production has a slight upward trend, but this takes into account the growing production of food products from inorganic substances. We also observe a continuous increase in consumption, including for food needs. We present data on the production of one of the most common crops - wheat.

When considering the world's most widely used crop, production tends to increase, taking into account that about $18 \%$ of production is used directly for feed, while about $70 \%$ - for food. Analysing these data, we conclude that to provide food for the population, countries around the world are actively importing certain needed products, including for the feed of certain animals. Note that most products are imported by developed countries, as the majority of their population has the necessary financial capabilities, but products such as beverages are in low demand because they are simple to produce and can be made from different components. It is also necessary to take into account the mass production of beverages from inorganic substances, which allows for the diversification this group of products. As Ukraine is traditionally one of the leaders in wheat exports, we will provide data on this group of countries. 
Table 3

World food resources of wheat

\begin{tabular}{|l|c|c|c|c|}
\hline \multirow{2}{*}{ World balance } & $2017 / 2018$ & $2018 / 2019$ & $\begin{array}{c}2019 / 20 \\
\text { (forecast) }\end{array}$ & $\begin{array}{c}2019 / 20 \text { to } \\
2018 / 19, \%\end{array}$ \\
\cline { 2 - 5 } & \multicolumn{4}{|c|}{ Million tonnes } \\
\hline Production & 759,0 & 730,2 & 767,0 & 5,0 \\
\hline Trade & 176,7 & 170,7 & 173,5 & 1,6 \\
\hline Total utilization & 738,9 & 747,3 & 756,9 & 1,3 \\
\hline including food & 508,9 & 514,2 & 519,4 & 1,0 \\
\hline feed & 136.1 & 141,4 & 143,6 & 1,5 \\
\hline \multicolumn{1}{|c|}{ other uses } & 94,0 & 91,7 & 94,0 & 2,5 \\
\hline
\end{tabular}

Source: compiled by the author on the basis of FAO Food Outlook - Biannual Report on Global Food Markets (2019).

Table 4

Top 10 world exporters of wheat

\begin{tabular}{|l|c|c|c|}
\hline \multicolumn{1}{|c|}{ Country } & 2016/17-2018/19 & $\begin{array}{c}2019 / 2020 \\
\text { (forecast) }\end{array}$ & $\begin{array}{c}2019 / 20 \text { to } \\
2016 / 17-2018 / 19, \%\end{array}$ \\
\hline \multicolumn{4}{|c|}{ Million tonnes } \\
\hline Russia & 34,5 & 35,0 & 0,5 \\
\hline USA & 26,6 & 27,0 & 0,4 \\
\hline EU & 23,7 & 23,5 & $-0,2$ \\
\hline Canada & 21,8 & 23,0 & 1,2 \\
\hline Ukraine & 17,3 & 17,0 & $-0,3$ \\
\hline Australia & 16,0 & 14,0 & $-2,0$ \\
\hline Argentina & 13,1 & 13,6 & 0,5 \\
\hline Kazakhstan & 8,0 & 8,0 & 0,0 \\
\hline Turkey & 4,8 & 4,0 & $-0,8$ \\
\hline Mexico & 1,0 & 1,3 & 0,3 \\
\hline
\end{tabular}

Source: Food Outlook - Biannual Report on Global Food Markets (FAO 2019).

Analysing these indicators, we can conclude that only 9 countries and EU countries export wheat in excess of 1 million tonnes, but because it is an important universal food and feed product, some countries that have potential conditions for its cultivation, including France, Italy, and Spain, prefer processing because it is more profitable from a national financial point of view. As for the USA and Canada, having significant territories and traditional schemes of cultivation of 
this culture, they occupy their own export niches that formed over the last several decades. Given that the countries have established traditional long-term permanent trade relations for food supplies, we should determine the trend in food imports in price equivalent.

Table 5

World imports of food resources

\begin{tabular}{|l|c|c|c|c|}
\hline \multirow{2}{*}{} & \multicolumn{2}{|c|}{ World } & \multicolumn{2}{c|}{ Developed countries } \\
\cline { 2 - 5 } & 2018 & $\begin{array}{c}2019 \\
\text { (forecast) }\end{array}$ & 2018 & $\begin{array}{c}2019 \\
\text { (forecast) }\end{array}$ \\
\cline { 2 - 5 } & \multicolumn{4}{|c|}{ USD billion } \\
\hline TOTAL IMPORT & 1510,1 & 1472,4 & 896,7 & 877,6 \\
\hline Meat & 168,9 & 168,6 & 103,2 & 102,3 \\
\hline Dairy & 92,4 & 91,9 & 57,8 & 57,6 \\
\hline Fish & 156,8 & 156,5 & 108,4 & 107,3 \\
\hline Cereals & 268,5 & 268,2 & 126,7 & 129,8 \\
\hline Vegetables and fruit & 277,9 & 274,7 & 194,1 & 190,9 \\
\hline Sugar & 46,0 & 46,0 & 22,5 & 22,4 \\
\hline Coffee, tea and cocoa & 111,2 & 100,7 & 80,9 & 73,3 \\
\hline Beverages & 116,7 & 112,6 & 26,8 & 26,0 \\
\hline $\begin{array}{l}\text { Vegetable oils and ani- } \\
\text { mal fats }\end{array}$ & 90,8 & 82,8 & 40,6 & 37,1 \\
\hline Oilseeds & 91,7 & 84,4 & 26,8 & 26,0 \\
\hline Other & 89,2 & 86,1 & 49,8 & 48,1 \\
\hline
\end{tabular}

Source: compiled by the author on the basis of FAO Food Outlook - Biannual Report on Global Food Markets (2019).

Trying to provide their own population with food, developed countries import it from other countries, preferring raw products or products of primary processing - cereals, coffee, tea, oils. In addition, only slightly more than $20 \%$ of world imports is developed countries importing beverages. We use these data in creating the concept of prospects for Ukrainian exports of agricultural and food products. Given that the prices for specific products have a significant impact on the export activity of countries, we present the dynamics of prices for the period of 2008-2018. 
Figure 1

\section{Change in price indices of certain foods}

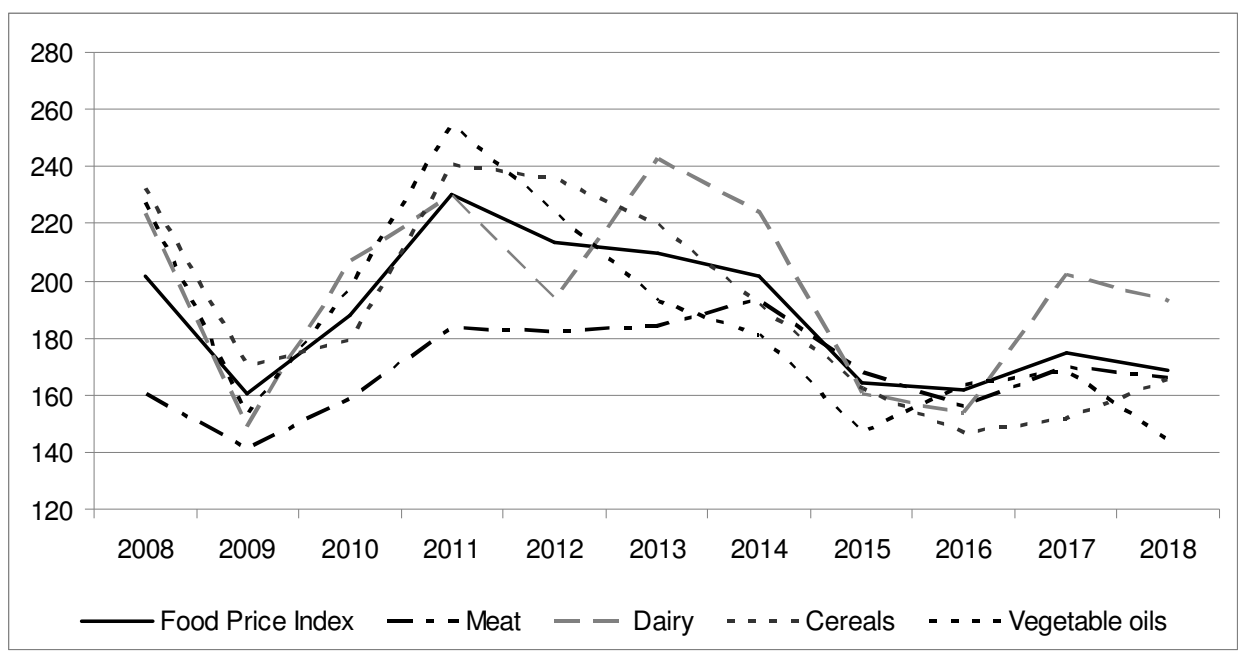

Source: created by the author on the basis of FAO Food Outlook - Biannual Report on Global Food Markets (2019).

Note that in determining food price indices, FAO specialists took into account 73 quotations of prices for relevant products, weighted by the average share of exports in 2002-2004. FAO Food Index is calculated as a weighted average of basic products such as dairy, meat, cereals, vegetable oils and sugar. The meat price index is calculated from the average prices for four types of meat, including poultry products, three beef products, three pork products and one lamb product, taking into account 27 price calculations in total. Prices for butter and cheeses were taken into account when determining the price indices for dairy products. The cereal price index is compiled using the International Grains Council (IGC) wheat price index, taking into account an average of ten different wheat prices, including 1 corn export offer and 16 rice offers. Rice data arrays are grouped into three groups, consisting of rice Indica, Japonica and Aromatic varieties. The price index for vegetable oils consisted of the average value of ten different oils, weighted by the average share of exports of each (FAO 2019).

Therefore, using the aforementioned method of calculation, we can conclude that there are significant fluctuations in prices during the year, as well as within each product group. In addition, there are price variations in some regions of the world, which is also published by FAO. These data form a methodological 
basis for making commercial decisions on the export strategy of each potential producer and supplier.

Having identified global trends in food exports, we will identify the real and potential opportunities of Ukraine in this context. To substantiate the prospects of exports of agricultural products, we find out its individual characteristics for 2018. According to the State Service for Geodesy, Cartography and Cadastre (State Geocadastre), Ukraine has 60.3 million hectares of land, which is $6 \%$ of the entire territory of Europe. The area of agricultural land is 42.7 million hectares $(70 \%$ of the territory of Ukraine), and arable land -32.5 million hectares $(78.4 \%$ of all agricultural land). At the same time, we have 17.4 million hectares of chernozem, which is $8 \%$ of all world reserves (StateGeoCadastre 2020). Let us determine the structure of exports, including food products.

Table 6

\section{Structure of Ukraine's commodity exports*}

\begin{tabular}{|l|c|c|c|c|c|c|c|}
\hline \multirow{2}{*}{ Commodity } & \multicolumn{7}{|c|}{ Year } \\
\cline { 2 - 9 } & 2013 & 2014 & 2015 & 2016 & 2017 & 2018 & 2019 \\
\hline Total, million USD & 62306 & 53902 & 38127 & 36362 & 43264 & 47335 & 50060 \\
\hline Food products & 17430 & 16669 & 14510 & 15281 & 17866 & 18710 & 22244 \\
\hline $\begin{array}{l}\text { live animals and } \\
\text { livestock products }\end{array}$ & 1083 & 1015 & 823 & 775 & 1108 & 1210 & 1277 \\
\hline plant products & 8849 & 8736 & 7921 & 8094 & 9316 & 9986 & 12914 \\
\hline fats and oils & 3997 & 3822 & 3300 & 3962 & 4605 & 4496 & 4732 \\
\hline finished food & 3501 & 3096 & 2466 & 2450 & 2837 & 3018 & 3221 \\
\hline $\begin{array}{l}\text { \% of finished, fats, } \\
\text { and oils in all food } \\
\text { products }\end{array}$ & 43,0 & 41,5 & 39,7 & 42,0 & 41,7 & 40,2 & 35,7 \\
\hline
\end{tabular}

*Data are provided without the temporarily occupied territories and the ARC

Source: compiled by the author on the basis of data of State Statistics Service of Ukraine (2019).

Assessing these data, it should be noted that crops from which foodstuffs are made, in particular sunflower, as well as rapeseed and maize, are extremely depleting of soils, so other countries do not consider them a priority for cultivation, choosing to import these crops or their products, in particular oils. It should also be noted that developed countries maintain strict control over crop rotations, and compliance with this requirement is a prerequisite for farming, for violation of 
Vol. 19. № 2 (73). April-June 2020

ISSN 2519-4070

which the sanctions are severe. Highlighting the share of processed agricultural products, we note that it has a steady downward trend, and it made up merely $35.7 \%$ in 2019.

The real export capabilities of Ukraine in 2018 are presented in Figure 2.

Figure 2

Ukraine in world agricultural exports

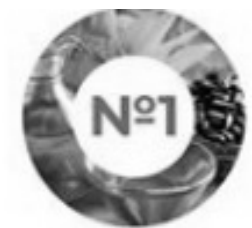

Sunflower

oil

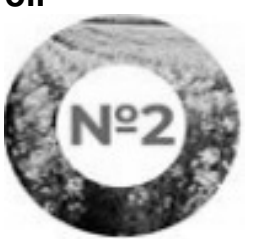

Rapeseed

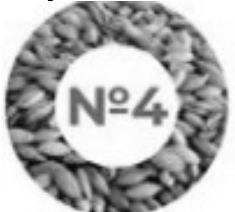

\section{Barley}

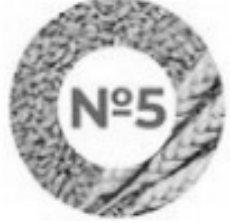

Wheat
$\$ 4.3$ billion

$\$ 1.3$ billion
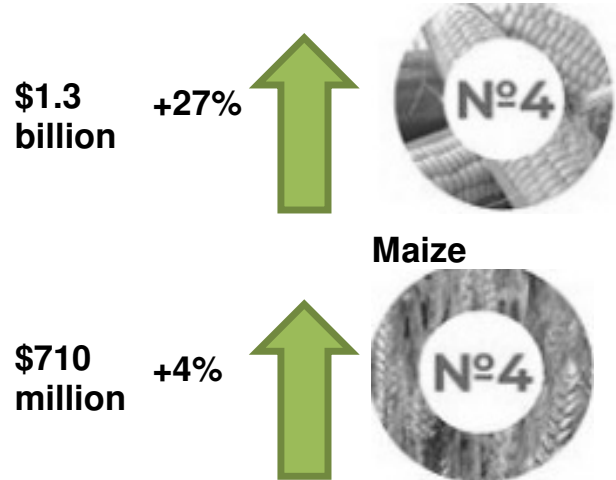

$\$ 3.7$ billion

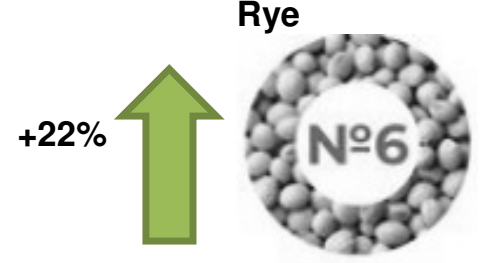

Soy

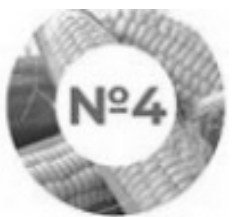

$\$ 975$ million

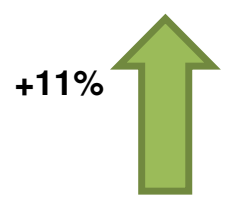

Sunflower meal

$\$ 5.2$ billion

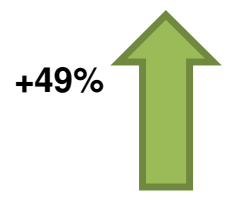

$\$ 3.9$ million $-75 \%$<smiles>C1CCCCC1</smiles>

$\$ 1.2$ $-16 \%$ billion

Source: Ukrainian Agribusiness Club (2020). 
Thus, according to these data, Ukraine ranks quite high in some exports. Note that there was an increase in exports in 2018 compared to the previous year in several categories, in particular sunflower oil, sunflower meal, rapeseed, maize, and barley. This trend is quite positive in terms of maintaining a niche in export supplies as well as in terms of their expansion. However, it is necessary to intensify the search for comprehensive supplies of products of tertiary processing of various crops and animal breeds. To identify the share of the most exported foods, we will provide relevant data.

Figure 3

Top 10 food exports in 2018, billion US dollars

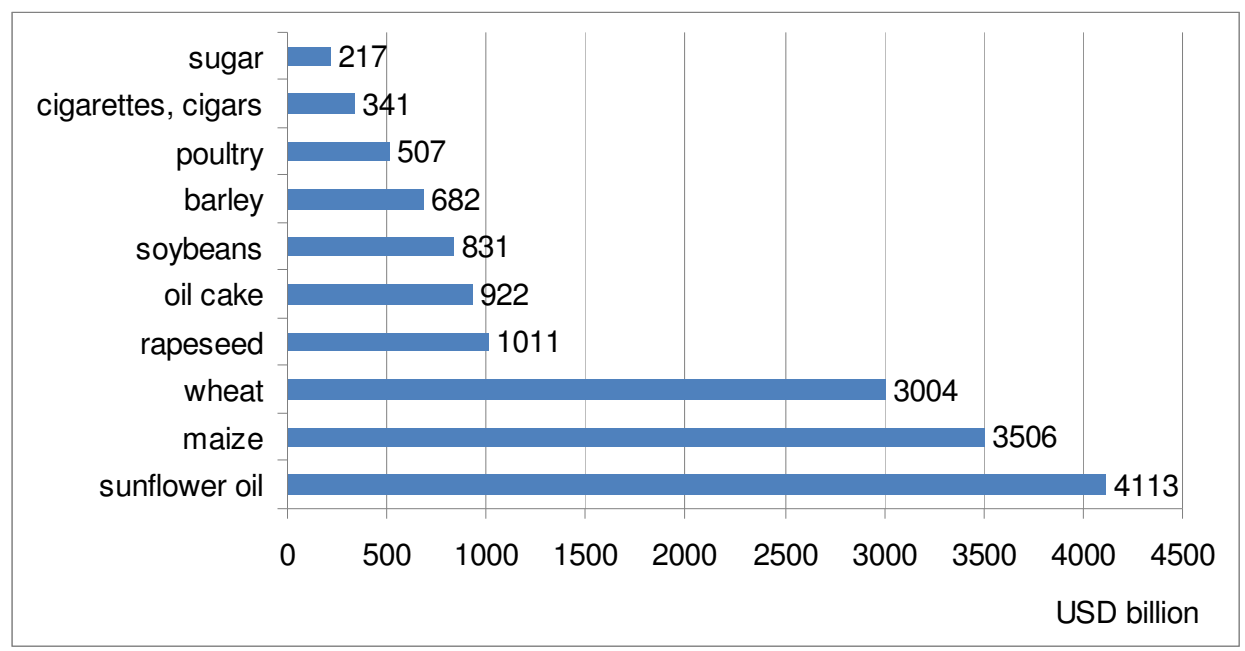

Source: State Statistics Service of Ukraine (2019).

Analysing these data, we note that the second to eighth places are occupied by crops and products of primary processing, with little added value, including sunflower oil, oil cake, and poultry. The next step is to determine the extent of potential increase in processing, in particular of grain crops. 
Table 7

Balance of grain crops for 2014/15-2018/19 marketing years

\begin{tabular}{|l|c|c|c|c|c|}
\hline & $2014 / 15$ & $2015 / 16$ & $2016 / 17$ & $2917 / 18$ & $2018 / 19$ \\
\hline $\begin{array}{l}\text { Collection area, } \\
\text { million hectares }\end{array}$ & 14,63 & 14,64 & 14,34 & 14,56 & 14,78 \\
\hline $\begin{array}{l}\text { Initial reserves, } \\
\text { million hectares }\end{array}$ & 6831 & 8981 & 6044 & 6454 & 6305 \\
\hline Production & 63859 & 60126 & 66088 & 61917 & 69800 \\
\hline Import & 197 & 211 & 223 & 279 & 237 \\
\hline Export & 35179 & 39924 & 45212 & 40956 & 47472 \\
\hline Supply & 70888 & 69318 & 72355 & 68649 & 76342 \\
\hline
\end{tabular}

Source: compiled by the author on the basis of data of Ambar Export (2019).

Assessing these indicators, we note that of the 32.5 million hectares of arable land only 14.78 million hectares or $45.4 \%$ were in use in 2019 . In general, during 2014/15 - 2018/19 MY there was an admittedly unstable positive trend towards increase in grain production and in 2019 almost 70 million tonnes will be harvested. At the same time, comparing the corresponding volumes of exports with the volumes of production, we note that there is an increase in the share of exports - from $55 \%$ in $2014 / 15$ MY to $68 \%$ in $2018 / 19$ MY, which is an increase of $13 \%$. Thus, the increase in the export niche in terms of grain supplies is a positive fact. However, from a national financial point of view, the cultivation of cereals, in particular wheat, with an average profit of $\$ 200$ per hectare (only successful farmers in favourable climatic and marketing years could reach $\$ 400$ per hectare) is not entirely satisfactory, given that processed cereal products give more profit. Thus, currently Ukraine is a supplier of vital types of agricultural raw materials, not offering products of tertiary processing, although it is obvious that processed agricultural products are three to five times more expensive. At the same time, the domestic consumer market is saturated with pasta and confectionery from Italy, Poland, Turkey and other countries made from Ukrainian raw agricultural materials.

The main countries to which Ukraine exports food products are presented in Figure 4. 
Figure 4

Top 10 importing countries of Ukrainian food exports in 2018, billion US dollars

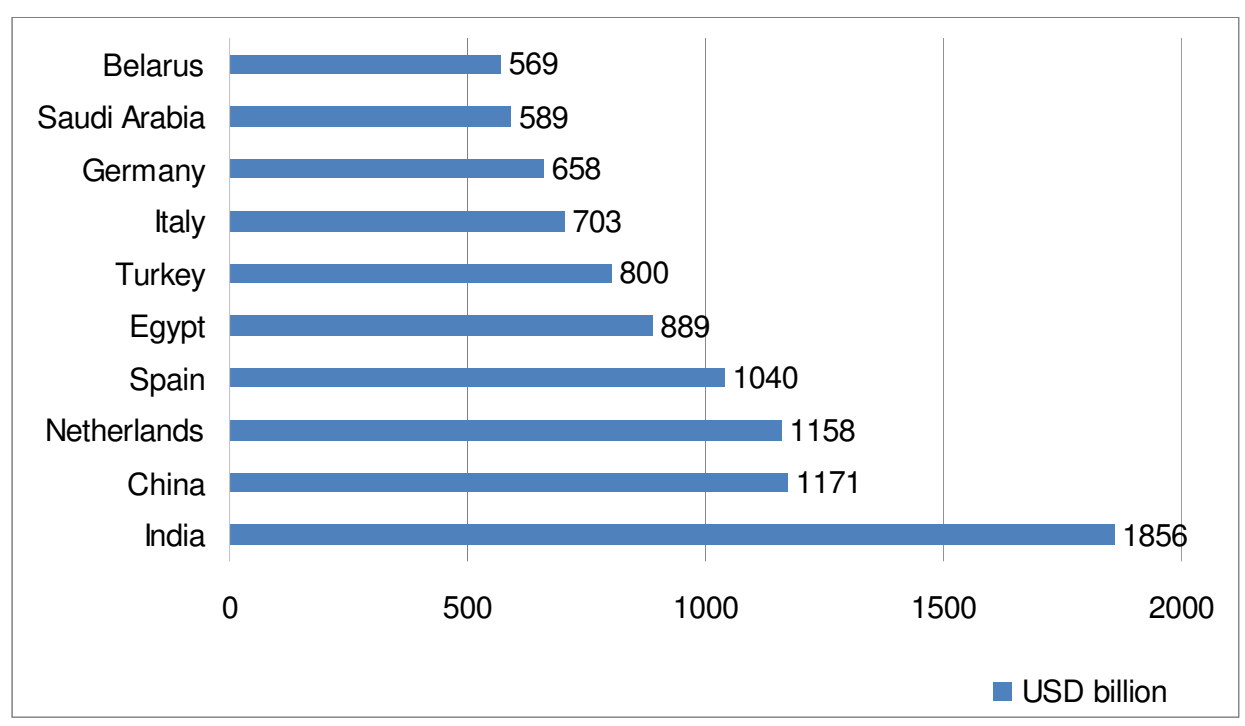

Source: created by the author on the basis of data of Ukrainian Agribusiness Club (2019).

According to these data, important importers of Ukrainian food exports include the countries of the Asian continent, then - the EU countries, in particular the Netherlands, Spain, Italy, Germany. It is obvious that there are significant reserves to increase food supplies to both traditional countries and new ones through tertiary processing. Summing up the results of the study, we can say that Ukraine is a major player on the global food export market, given the first places in several positions. To increase the volume of food exports, the concept of prospects for exports of agricultural and food products of Ukraine is proposed, which includes scientifically sound provisions, principles and a model.

\section{Provisions.}

1. Using export advantages of Ukraine. Ukraine has more than 42 million hectares of agricultural land (including 17.4 million hectares of chernozem, which is $8 \%$ of all world reserves), relatively favourable climatic conditions, which facilitate cultivation of grains, vegetables, fruits, berries, wild plants, and breeding of domestic animals. All this creates the conditions for a significant increase in food exports. In addition to these factors, the technological potential of the food indus- 
try contributes to the manufacture of processed products. At the same time, some problems related to land sales, provision of financial resources, etc. significantly reduce this potential, so they must be overcome with a professional state approach.

2. Consolidation of traditional markets and intensification of the search for new ones. It is necessary to intensify the search for other regions and countries that need food products because of the significant problems with the Russian market for these products. As this is a task of national importance, employees of our embassies and consulates abroad, specialists of relevant ministries and departments should take an active part in its pursuit. It is necessary to continue work on concluding interstate agreements with an emphasis on promoting Ukrainian goods on the markets of certain countries. Relevant producer associations and commercial establishments in this field should also play an important role.

3. Increasing public funding of the agro-industrial complex. In recent years, this support amounted to: UAH 5.3 billion in 2017, UAH 4.2 billion in 2018, UAH 3.1 billion in 2019, UAH 4.3 billion in 2020 (forecast) (Ukrinform 2019; Information and analytical portal of the AIC of Ukraine 2019, 2020), which is extremely little. Note that in 2018, EU support used state and EU funds and amounted to (in billion euros): in France - 7.4, Germany - 5.0, Spain - 4.9, Great Britain - 3.6, Poland - 3.1, Romania - 1.9, the Czech Republic - 0.9, Bulgaria - 0.8 (Ovcharova 2016). Therefore, Ukrainian state support for domestic agricultural food producers should be increased significantly. It is also necessary to provide significant state support to relevant research institutions, enterprises that manufacture technological equipment, and enterprises that manufacture competitive export products.

\section{Principles.}

1. Scientific substantiation of development of the agro-industrial branches. This traditional principle of forming new qualities of the system should be applied to the current state of these industries. Some disjointed concepts and programmes on the development of individual segments of the agro-industrial complex solve only certain local development problems of limited theoretical and methodological justification, and moreover, sometimes are merely declarative. For example, Order of the Cabinet of Ministers of Ukraine of December 27, 2017 № 1017-p «On approval of the Export Strategy of Ukraine («Road Map» of Strategic Trade Development) for 2017-2021» (Cabinet of Ministers of Ukraine 2017) provides only a list of measures of government agencies involved in the organization of export deliveries of products without naming the ways of searching for potential partners, the responsibility of officials, or financial, organizational, legal support. That is why there should be developed a Doctrine of agro-industrial complex development with strategies, programmes, plans of industry development, listing concrete terms, responsibility of executors, and types of support. One of the components of this Doctrine should be the concept of prospects for the export of agricultural and food products of Ukraine. 

concept of prospects

2. Emergent effect. Export deliveries are a «tip of the iceberg» that completes the cycle. On the example of cereals: preparation for sowing $\rightarrow$ sowing campaign $\rightarrow$ cultivation $\rightarrow$ harvest $\rightarrow$ storage $\rightarrow$ delivery for export or processing $\rightarrow$ manufacture of finished food products $\rightarrow$ determining target consumers $\rightarrow$ delivery. The current lack of coordination between farmers, processors, exporters and logistics organizations is not conducive to efficient organization of export deliveries in view of tertiary food processing. That is why this process needs to be properly organized, with suggestions from all process participants, including government officials, think tanks, professional associations and research institutions.

3. Local self-government involvement in joint actions on the organization of agricultural production and manufacture of finished food products. At present, Ukraine is implementing a comprehensive administrative and territorial reform, in particular creating amalgamated territorial communities, introducing decentralization, and expanding the powers of local self-governments. Therefore, coordination of agricultural and non-agricultural land use is an additional reserve for the production of finished food.

\section{Model.}

It focuses on the theoretical substantiation of the manufacture of finished food products of proper quality for export.

This model is the theoretical basis for the organization of export deliveries, in particular foods of tertiary processing. According to this model, a specific mechanism is created, which provides for the sowing of crops, animal husbandry, use of certain resources, including financial ones. It takes into account the participation of local self-governments and promotes interest and coordination between all stakeholders in the process of making finished food exports.

\section{Conclusions}

Having summarized global trends in the market of food exports, including convenience foods, having analysed the potential of the domestic agro-industrial complex in the context of creating the concept of prospects for exports of agricultural and food products of Ukraine, the following conclusions have been made.

1. It is determined that there is a permanent positive global trend of increasing food exports, which is caused by the population growth on the one hand, and the reduction of areas for growing crops and fish stocks on the other. In this context, Ukraine, with significant reserves of chernozems and technological capacity for processing agricultural products, can become a powerful player in the international food export market given certain concerted actions of state authorities, local self-governments and entrepreneurs. 


\section{Figure 5}

\section{Model of export deliveries development}

\begin{tabular}{|c|c|}
\hline 1 & $\begin{array}{l}\text { Investigation of the available strategies, programmes, } \\
\text { development plans of the agro-industrial complex }\end{array}$ \\
\hline \multirow[b]{2}{*}{ II } & $\downarrow$ \\
\hline & Clarification and addition of components to this paradigm \\
\hline \multicolumn{2}{|r|}{ 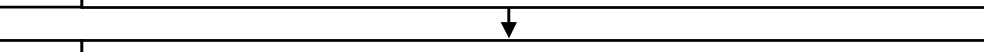 } \\
\hline III & Setting the tasks for the development of export potential \\
\hline \multicolumn{2}{|r|}{$\frac{1}{t}$} \\
\hline IV & Designation of executors, terms, resources \\
\hline \multicolumn{2}{|r|}{$\downarrow$} \\
\hline $\mathrm{V}$ & $\begin{array}{l}\text { Identification of regions, groups of enterprises } \\
\text { for potential export deliveries }\end{array}$ \\
\hline \multicolumn{2}{|r|}{$\downarrow$} \\
\hline VI & $\begin{array}{l}\text { Detection of export niches in regions, countries, as well as import } \\
\text { requirements, including microbiological, technological, customs }\end{array}$ \\
\hline \multicolumn{2}{|r|}{$\downarrow$} \\
\hline VII & Monitoring of pricing \\
\hline \multicolumn{2}{|r|}{$t$} \\
\hline VIII & Supervision over agreement conclusion \\
\hline \multicolumn{2}{|r|}{$t$} \\
\hline IX & Organization of export deliveries \\
\hline
\end{tabular}

Source: created by the author.

2. It is established that Ukraine is among the leaders in the export of sunflower oil, sunflower meal, rapeseed, maize, barley, and rye. However, it is obvious that the quality of soil is negatively affected by the cultivation of sunflower and maize on the same agricultural land for several years in a row. Therefore, it is necessary to adhere to crop rotation, which is practiced in developed countries. That is why it is necessary to introduce state control over crop rotations, taking into account the Articles 13 and 14 of the Constitution of Ukraine. Article 13 states that «The land, its minerals, air, water and other natural resources within the territory of Ukraine, natural resources of its continental shelf and exclusive (sea) economic zone, are the property of the Ukrainian people», while Article 
14 clarifies that «Land is the main national wealth, which is under special protection of the state».

3. The analysis of the global trends in the price offers for some crops and food products including meat, cereals, and vegetable oils has found that they are unstable and significantly depend on many factors, including force majeure. Therefore, it is necessary to monitor the price offers continuously and to conduct preventive measures when forecasting the volumes of export deliveries to specific countries and regions of the world.

4. It is proved that in Ukraine the area under crops is between 14.63 million hectares in 2014 and 14.78 million hectares in 2018, which is approximately $45.4 \%$ of the 32.5 million hectares of arable land. This is quite a significant indicator, however, exporting these crops, in particular wheat and corn, is financially unprofitable because the products of their processing can be exported at several times the price. It is obvious that it is impractical to reduce the export of these crops significantly, as it would mean losing traditional markets. However, it is possible to reduce the supply of these crops as the number of buyers of finished products increases. It is also necessary to adhere to the national balance of food, not allowing the import of those foods that can be produced in Ukraine.

5. Emphasis is placed on the need to increase state financial support for the structures of the agro-industrial complex, as the volume of this funding is much smaller than in the EU and acts as a deterrent to increasing exports.

6. It is stated that in order to improve the situation in the agro-industrial complex significantly, in particular with regard to food exports, it is advisable to significantly change and supplement the paradigm of its development, including with regard to export deliveries. That is why the proposed concept of prospects for the export of agricultural and food products of Ukraine, which is part of this paradigm, will help improve the situation with food exports.

\section{References}

1. Ambar Export. (2019). Domestic grain has a trend towards abroad. Retrieved from: https://ambarexport.ua/ru/blog/export-grain-from-ukraine

2. Artamonova, H. (2019). Ukraine's foreign trade with the EU: opportunities and challenges. Journal of European Economy, Vol. 18, No. 3, pp. 283-294.

3. Bazhenova, O., Bochi, A., Povoroznyk, V. (2019). The impact of the EUUkraine Deep and Comprehensive Free Trade Area on the Ukrainian industrial sector. Democracy House. Retrieved from: http://library.fes.de/pdffiles/bueros/ukraine/15250.pdf 
ISSN 2519-4070

4. Burlaka, N., Baltremus, O. (2016). State and Prospects of Agribusiness in Ukraine. Economy, Finances, Management: Topical Issues of Science and Practical Activity, Issue No. 6, pp. 31-38.

5. Cabinet of Ministers of Ukraine. (2017). Order of the Cabinet of Ministers of Ukraine of December 27, 2017№ 1017-p «On approval of the Export Strategy of Ukraine («Road Map» of Strategic Trade Development) for 2017-2021». Retrieved from: https://zakon.rada.gov.ua/laws/show/1017-2017-\%D1\%80

6. Constitution of Ukraine. Document $254 \mathrm{~K} / 96-\mathrm{BP}$, in force, current edition Edition of January 1, 2020, grounds - 27-IX, Retrieved from: https://zakon.rada.gov.ua/laws/show/254\%D0\%BA/96-\%D0\%B2\%D1\%80

7. do Nascimento, R., Ferreira, O., De Paula, A., Neto, V. (2019). Nanomaterials Applications for Environmental Matrices: Water, Soil and Air. Elsevier. Retrieved from: https://books.google.com.ua/books?id=k4udDwAAQBAJ\&pg $=$ PA9\&lpg=PA9\&dq=Earth\%27s+population $+2015+7383,+2030+8551 \&$ source =bl\&ots=mFS4BPu4ad\&sig=ACfU3U3bfjATVL0ZVtwHFS9FfeFHK8Hs9A

8. FAO. (2019). Food Outlook - Biannual Report on Global Food Markets. Rome. Licence: CC BY-NC-SA 3.0 IGO. Retrieved from: http://www.fao.org/3/ca4526en/ca4526en.pdf

9. FAO. (2019). Tracking Progress on Food and Agriculture-Related SDG Indicators: A report on the indicators under FAO custodianship. Retrieved from: http://www.fao.org/fileadmin/templates/SDG-progress-report/2019-final/sdgprogress-report-print-RU.pdf

10. Gryshova, I. (2016). Competitiveness of agriculture enterprises as the main factor of sustainable development of agricultural sphere. Ukrainian Journal of Applied Economics, Vol. 1, No. 2, pp. 25-35.

11. Information and analytical portal of the AIC of Ukraine. (2019). Financing of the agro-industrial complex in 2017. Retrieved from: https://agro.me.gov.ua/ua/napryamki/finansova-politika/finansuvannya-zderzhavnogo-byudzhetu/stan-finansuvannya-apk-u-2017-roci

12. Information and analytical portal of the AIC of Ukraine. (2020). Status of financing of agro-industrial complex support programs in 2019. Retrieved from: https://agro.me.gov.ua/ua/pidtrimka/stan-finansuvannya-program-pidtrimki-apku-2019-roci

13. Kasych, A.O., Tsokalo, O.A. (2015). State and Prospects of Ukraine Trade Relations with the European Union. Scientific Bulletin of Kherson State University. Series «Economic Sciences", Vol. 13, No. 3, pp. 23-28.

14. Markova, Ye., Shestakovska, T. (2017). Features of the development of the agricultural sector of Ukraine's economy in terms of European integration. Journal of European Economy, Vol. 16, No. 4, pp. 414-425. 

concept of prospects

15. Naumova, L., Naumov, O., Lebedeva, V. (2016). Concept of the development of agrarian and industrial production on the basis of cross-sector integration. Bulletin of Sumy NAU (Economics and Management series), Vol. 1, No. 67 , pp. 38-42.

16. Nepriadkina, N. (2018). Foreign trade development between Ukraine and the eu in agricultural sphere: specifics and prospects. The Journal of V.N. Karazin Kharkiv National University Series «International Relations. Economics. Country Studies. Tourism», No. 7, pp. 60-65. Retrieved from: http://nbuv.gov.ua/UJRN/VKhMv_2018_7_11.

17. Okhrimenko, O., Makarenko, A. (2018). Integrated development of export potential of Ukrainian agroindustrial complex in the context of overseas connections. Journal «Efektyvna ekonomika», No. 4.

18. Ovcharova, L. (2016). Support for farmers in EU countries. European Information and Research Center. Retrieved from: https://radaprogram.org/ sites/default/files/infocenter/piblications/subsydiyi_fermeram.pdf

19. Pakhucha, E., Filimonov, Y., Leshchenko, L. (2019). Structural changes in Ukraine's foreign trade in agricultural products. Journal «Efektyvna ekonomika», No. 3.

20. Pugachov, M. (2017). Agrarian sector of economy of Ukraine in terms of institutional changes. "The Economy of Agro-Industrial Complex» International Scientific and Production Journal, No. 5, pp. 12-18.

21. State Service of Ukraine for Geodesy, Cartography and Cadastre. (2020). Statistics. Retrieved on January 17 from: https://land.gov.ua/info/statystyka/

22. State Statistics Service of Ukraine. (2019). Commodity structure of foreign trade. Retrieved from: http://www.ukrstat.gov.ua/operativ/operativ2019/zd/ tsztt/tsztt_u/tsztt1219_u.htm!

23. Ukrainian Agribusiness Club. (2019). Top 10 markets for Ukrainian products in 2018, million dollars US. Retrieved from: http://ucab.ua/ua/doing_ agribusiness/zovnishni_rinki/osnovni_pokazniki_zovnishnoi_torgivli_ukraini

24. Ukrainian Agribusiness Club. (2020). Trade Map, Retrieved from: http://ucab.ua/en

25. Ukrinform. (2019). State support for farmers in 2020: the priority industry has become known. Retrieved from: https://www.ukrinform.ua/rubric-economy/ 2822559derzavna-pidtrimka-agrariiv-u-2020-roci-stalo-vidoma-prioritetna-galuz.html. 